\title{
Streptococcus mutans in denture stomatitis patients under antifungal therapy
}

\author{
Streptococcus mutans em pacientes com estomatite protética \\ submetidos à terapia antifúngica
}

\begin{abstract}
Purpose: To assess the number of Streptococcus mutans in saliva of patients with denture stomatitis before and after antifungal therapy.

Methods: After examining 93 patients, 47 were selected for fungal test. Then, from this sample, thirty patients were selected: 15 with positive and 15 with negative diagnosis for candidiasis that were evaluated for $S$. mutans counting, salivary flow and buffer capacity evaluation. Oral hygiene and prosthesis hygiene, period using prosthesis, lesion type and salivary data were related with clinical laboratorial characteristics of the patients with Candida.

Results: The most frequent lesions were type I (43.5\%) and II (53.5\%). The amount of S. mutans was six times higher in patients with candidiasis and it was associated with low salivary flow and poor oral hygiene. After therapy, a reduction of $S$. mutans was verified particularly in patients with normal salivary flow. The values ranged from 0.01 to $3.88 \times 10^{4} \mathrm{cfu} / \mathrm{mL}$.

Conclusion: The data suggest that Streptococcus spp collaborates with Candida spp in the etiology and pathogenesis of denture stomatitis. The use of oral antimicrobial agents may provide a beneficial effect for denture stomatitis patients that are under antifungal therapy and that have poor oral hygiene and unfavorable salivary parameters.
\end{abstract}

Key words: Dental prosthesis; antifungal agents; Candida; Streptococcus mutans

\section{Resumo}

Objetivo: Verificar o número de Streptococcus mutans em saliva de pacientes com estomatite protética antes e após a terapia antifúngica.

Metodologia: Após exame clínico de 93 pacientes, 47 foram selecionados para exame micológico e desta amostra foram selecionados trinta pacientes: $15 \mathrm{com}$ diagnóstico positivo e 15 com diagnóstico negativo de candidose foram avaliados para contagem de S. mutans, determinação de fluxo salivar e capacidade tampão. Higiene bucal e da prótese, tempo de confecção, tipo de lesão e dados salivares foram relacionados com características clínicas e laboratoriais de Candida.

Resultados: As lesões frequentes foram dos tipos I (43,5\%) e II (53,5\%). A quantidade de S. mutans foi seis vezes maior em pacientes com candidose e foi associada com baixo fluxo salivar e higiene oral deficiente. Após a terapia, a redução de S. mutans foi verificada particularmente em pacientes com fluxo salivar normal. Os valores variaram de 0,01 a 3,88 UFC/ml x 104.

Conclusão: Os dados sugerem que os Streptococcus colaboram com Candida spp na etiopatogenia da estomatite protética. $\mathrm{O}$ uso de agentes antimicrobianos orais pode propiciar efeito benéfico para pacientes com estomatite protética submetidos à terapia antifúngica e que apresentam higiene oral deficiente e parâmetros salivares desfavoráveis.

Palavras-chave: Prótese dentária; agentes antifúngicos; Candida; Streptococcus mutans

\author{
Laurylene César de S. Vasconcelos a \\ Fábio Correia Sampaio a \\ Maria Carméli Correia Sampaio b \\ Maria do Socorro Vieira Pereira ${ }^{c}$ \\ Maria Helena Pereira Peixoto ${ }^{c}$
}

\begin{abstract}
- Department of Clinical and Social Dentistry, Federal University of Paraíba, João Pessoa, PB, Brazil

b Department of Pharmaceutical Sciences, Federal University of Paraíba, João Pessoa, PB, Brazil

c Department of Molecular Biology, Federal University of Paraíba, João Pessoa, PB, Brazil
\end{abstract}

\author{
Correspondence: \\ Laurylene César de Souza Vasconcelos \\ R. Maria Helena da Rocha, 113 - Aeroclube \\ João Pessoa, PB - Brasil \\ 58036-823 \\ E-mail: laurylene@uol.com.br
}

Received: May 20, 2009

Accepted: March 31, 2010

Conflict of Interest Statement: The authors state that there are no financial and personal conflicts of interest that could have inappropriately influenced their work.

Copyright: (C) 2010 Vasconcelos et al.; licensee EDIPUCRS. This is an Open Access article distributed under the terms of the Creative Commons AttributionNoncommercial-No Derivative Works 3.0 Unported License. 


\section{Introduction}

The surface of acrylic dentures usually host several microorganisms (fungi and bacteria) that are difficult to remove even by vigorous mechanical cleaning or chemical agents (1). This environment produced by the prosthesis can promote yeast proliferation with or without predisposing local factors (2).

Denture stomatitis is an oral pathology of multifactorial etiology that affects a large number of patients using complete or partial dentures. The main etiologic factors related to denture stomatitis are trauma, poor oral hygiene and infection with Candida species. In general, the patients with denture stomatitis complain of edema, hyperemia, pain in the affected areas and burning mouth when a low salivary flow is taking place $(3,4)$.

The adhesion of Candida cells to oral surfaces is a key initial event in pathogenesis of oral candidiasis, and the complex structure of oral flora with mixed species communities can intermediate the predisposition for many oral conditions including candidiasis (3). There are evidences that denture stomatitis is not a result of $C$. albicans solely, but rather it is an outcome of multispecies biofilms that may include Streptococcus mutans and Staphylococcus aureus $(5,6)$. In fact, it has been already observed that co-adhesion between C. albicans and many Streptococcal spp. promotes oral colonization by yeast cells (6). Streptococcus mutans is a frequent member of acrylic dentures surfaces and if incubated simultaneously with Candida albicans may compete for biding sites but it can also promote yeast adhesion (5). This bacteria-yeast interaction has been a matter of investigation of many in vitro and in vivo studies (5,7-10). The analysis of the in vitro adherence of $S$. mutans and C.albicans can contribute to the understanding of the behavior of these organisms in the dental plaque. The interaction of these microorganisms in a combined culture can be understood as mutualistic, once both seem to be favored (11).

The adhesion is regarded as the first step for oral biofilm formation and distinct mechanisms of adherence can contribute for candidiasis resistance to antifungal therapeutic agents (8). In complex biofilms such as those found in the oral cavity, the ability of yeast to agglutinate with bacteria can be mediated by species interaction within the biofilm as well as by external factors like saliva, oral hygiene and exposure to antimicrobial agents $(8,9)$. Despite the in vitro evidences of the Candida-bacteria interaction, few studies have investigated the $S$. mutans in patients with candidiasis or yeast related diseases $(10,12)$. The aim of this study was to assess the number of Streptococcus mutans in saliva of patients with diagnosis of denture stomatitis before and after antifungal therapy.

\section{Methods}

The study protocol was approved by the Local Ethical Committee of the Federal University of Paraíba, João Pessoa, PB, Brazil. Only patients who were assisted at the dental clinic and signed the consent were selected for the research. The criterion for participating in the research was dental prosthesis users. The exclusion criteria were: patients with systemic predisposing or confounding factor (diabetes, hyperthyroidism, immune diseases, radiotherapy and chemotherapy treatments), use of medicines that could affect any Candida infection such as antidepressive, immunosuppressive and anti-bacterial agents (2).

A total of 93 patients were examined and forty seven presented clinical signs of denture stomatitis. The clinical signs were classified in three stages described by Newton as pin-point hyperemia, diffuse hyperemia and nodular hyperemia of the entire denture area (13).

Swabs were used for collecting material from prosthesis (P1) and palatine lesions (P2) of patients with candidiasis. The material was subsequently placed on CHROMagar Candida for culture, isolation and identification of fungi species. CHROMagar is a selective and differential medium that allows selective isolation of yeasts and simultaneously. identifies (by color reactions and colony morphology) colonies of $C$. albicans ,C. tropicalis and C. Krusei with a high degree of accuracy (14).

Mycological exams as described previously were carried out in this sub-sample (4). The presence of Candida infection was confirmed in 32 patients, but only 15 presented more than $20 \mathrm{cfu}$ (Colony Forming Units), a level which characterizes infection (1). Finally, the sample was composed of 30 patients with denture stomatitis: 15 with candidiasis and 15 without candidiasis.

Antifungal therapy was applied for the 15 patients who were positive for candidiasis. The patients received a tube of a commercial antifungal medicine (Daktarin ${ }^{\circledR}$ gel oral, Janssen Cilag Farmacêutica, $40 \mathrm{~g}$ ) and instruction for using 3 times a day for two weeks. They were instructed to use a sufficient amount of gel that could cover the affected areas as recommended by the manufacturer. Denture were cleaned each night with neutral soap and washed with tap water. Patients were strongly requested to avoid using dentures at night during the test period.

Before starting the therapeutic period, oral hygiene parameters and salivary test were carried out before the therapeutic period of 2 weeks. Mycological and microbiological tests were carried out twice: before the patients have started using the medicine and two days after finishing the therapeutic period. Oral hygiene and prosthesis hygiene parameters were collected according to the guidelines of Sakki et al. (15). Saliva parameters (stimulated salivary flow rate and buffer capacity) were collected as described by Krasse et al. (16). The patients were classified in three levels of salivary flow rate: a) hiposalivation $=0.7 \mathrm{~mL} / \mathrm{min}, \mathrm{b}$ ) intermediate salivary flow $=0.71$ up to $1.0 \mathrm{~mL} / \mathrm{min}$ and $\mathrm{c}$ ) normal salivary flow when above $1.1 \mathrm{~mL} / \mathrm{min}$. For buffer capacity, the reference levels were considered as normal for $\mathrm{pH}$ above 5 and low for $\mathrm{pH}$ below or equal to 4 . The $\mathrm{pH}$ measurements were determined using indicate paper but intermediate values were checked in $\mathrm{pH}$ electrode for final classification (below of above 5.5). 
The S. mutans counting was carried out for all 30 patients at baseline and for 15 patients after using the antifungal medicine. Non-stimulated saliva samples were placed in Brain Heart Infusion (BHI, Difco) and later on MSB medium: mitis salivarius agar (Difco) supplemented with 440 $\mathrm{mM}$ sucrose, $39 \mathrm{mM}$ potassium tellurite and 0.2 units $/ \mathrm{mL}$ of bacitracin, as recommended by Gold et al. (17). All procedures were in duplicate.

Statistical analysis was carried out using SPSS (Statistical Package for Social Sciences) v.10.0. The assumptions of equality of variances and normal distribution of errors were checked for all numerical variables. Since the distribution of the errors was homogeneous, data were tested by Student's $\mathrm{T}$ test with a significance level of $5 \%$.

\section{Results}

Most patients were female $(\mathrm{n}=24)$ with an age range between 27 and 69 years-old. Within this range, the most frequent observations were between 49 up to 59 -years-old. The lesions types observed were type I $(43.5 \%)$ and type II (53.5\%). Type III composed $3 \%$ of the lesions.

Candida albicans was the predominant yeast isolated (86.6\%) followed by. C. tropicalis, C. parapisilosis, C. glabrata e C. krusei.

Table 1 shows the mean fcu $/ \mathrm{mL}$ of $S$. mutans and Candida spp of all patients. Ten subjects who showed high counts of Candida in the prosthesis were positive for candidiasis and were also with high number of $S$. mutans in saliva.

Table 1. Mean cfu/mL of S. mutans and Candida spp of 30 patients (15 patients positive and 15 negative for Candida).

\begin{tabular}{|c|c|c|c|c|c|}
\hline \multirow{2}{*}{$N$} & \multicolumn{2}{|c|}{$\mathrm{N}$ of colonies of Candida spp } & \multirow{2}{*}{ Candidiasis } & \multirow{2}{*}{$\begin{array}{c}\text { S. mutans } \\
\text { Percentile }(50 \%)\end{array}$} & \multirow{2}{*}{$\begin{array}{c}\text { S. mutans } \\
\left.\text { (n } \times 10^{4} \mathrm{cfu} / \mathrm{mL}\right)\end{array}$} \\
\hline & Prosthesis & Palate & & & \\
\hline 1 & 0 & 0 & - & - & 1 \\
\hline 2 & 0 & 0 & - & - & 3 \\
\hline 3 & 0 & 0 & - & - & 11 \\
\hline 4 & 0 & 0 & - & - & 12 \\
\hline 5 & 0 & 0 & - & - & 13 \\
\hline 6 & $>200$ & 17 & + & - & 14 \\
\hline 7 & 0 & 0 & - & - & 16 \\
\hline 8 & 0 & 0 & - & - & 16 \\
\hline 9 & 103 & $>200$ & + & - & 17 \\
\hline 10 & $>200$ & 0 & + & - & 17 \\
\hline 11 & 0 & 0 & - & - & 23 \\
\hline 12 & 0 & 0 & - & - & 24 \\
\hline 13 & $>200$ & 122 & + & - & 26 \\
\hline 14 & 0 & 0 & - & - & 29 \\
\hline 15 & 0 & 0 & - & - & 29 \\
\hline 16 & $>200$ & 113 & + & - & 29 \\
\hline 17 & 0 & 0 & - & + & 53 \\
\hline 18 & 0 & 0 & - & + & 55 \\
\hline 19 & 0 & 0 & - & + & 58 \\
\hline 20 & 0 & 0 & - & + & 85 \\
\hline 21 & $>200$ & 20 & + & + & 92 \\
\hline 22 & $>200$ & 126 & + & + & 154 \\
\hline 23 & $>200$ & 0 & + & + & 174 \\
\hline 24 & 116 & 19 & + & + & 175 \\
\hline 25 & $>200$ & 149 & + & + & 206 \\
\hline 26 & $>200$ & 0 & + & + & 254 \\
\hline 27 & $>200$ & 93 & + & + & 322 \\
\hline 28 & 183 & 0 & + & + & 382 \\
\hline 29 & 170 & 0 & + & + & 446 \\
\hline 30 & $>200$ & 39 & + & + & 495 \\
\hline
\end{tabular}


Table 2 shows the reduction in salivary $S$. mutans $(\mathrm{cfu} / \mathrm{mL})$ after the antifungal therapy. In percentages, the differences range from 3.8 up to $82 \%$ with a mean reduction of $45 \%$.

Table 3 presents the mean (SD) values ( $\mathrm{cfu} / \mathrm{mL})$ of $S$. mutans of patients before the antifungal therapy (baseline) according to other parameters. Table 4 presents the distribution of patients categorized in low and high $S$. mutans counting (cfu/mL) of patients who with and without candidiasis. The estimate amount S.mutans of in saliva among patients with deficient hygiene was ten fold higher compared to those with good hygiene. Among those patients with deficient hygiene $(\mathrm{n}=13)$, the mean $(\mathrm{SD})$ values $(\mathrm{cfu} / \mathrm{mL})$ of S.mutans were 2.24(1.50) and 0.93(0.50) before and after the antifungal therapy, respectively. For those with good hygiene $(n=2)$ there values were $0.21(0.10)$ and $0.12(0.01)$, respectively.

Table 2. Mean, standard deviation and confidence interval of S. mutans (cfu/mL) in saliva of patients $(n=15)$ before and after the use of antifungal medicine.

\begin{tabular}{|c|c|c|c|}
\hline \multirow[b]{2}{*}{$\mathrm{N}$} & \multicolumn{2}{|c|}{ Antifungal therapy } & \multirow{2}{*}{$\begin{array}{c}\text { Difference } \\
\text { ( } \mathrm{n} \times 10^{4} \mathrm{cfu} / \mathrm{mL} \text { ) }\end{array}$} \\
\hline & $\begin{array}{r}\text { Before (baseline) } \\
\left(\mathrm{n} \times 10^{4} \mathrm{cfu} / \mathrm{mL}\right)\end{array}$ & $\begin{array}{c}\text { After } \\
\left(\mathrm{n} \times 10^{4} \mathrm{cfu} / \mathrm{mL}\right)\end{array}$ & \\
\hline Mean & 1.97 & 0.83 & 1.14 \\
\hline Standard deviation & 1.56 & 0.57 & 1.27 \\
\hline Confidence interval & $1.10-2.83$ & $0.51-1.14$ & $0.43-1.84$ \\
\hline
\end{tabular}

Table 3. Mean (SD) of fcu/mL of S. mutans (baseline), time of use of prosthesis, salivary flow rate, buffer capacity of patients who with and without candidiasis.

\begin{tabular}{lcccccc}
\hline \multicolumn{1}{c}{ Candidiasis } & $\mathrm{N}$ & $\begin{array}{c}\text { S. mutans } \\
\text { (n x 10 } \mathrm{cfu} / \mathrm{mL})\end{array}$ & $\begin{array}{c}\text { Period of using prosthesis } \\
(\mathrm{months})\end{array}$ & $\begin{array}{c}\text { Salivary flow rate } \\
(\mathrm{mL} / \mathrm{min})\end{array}$ & $\begin{array}{c}\text { Buffer capacity } \\
(\mathrm{pH})\end{array}$ \\
\hline Negative & 15 & $0.3(0.22)^{\mathrm{a}}$ & $69.1(49.3)^{\mathrm{a}}$ & $1.2(0.3)^{\mathrm{a}}$ & $6.6(0.7)^{\mathrm{a}}$ \\
Positive & 15 & $1.97(1.56)^{\mathrm{b}}$ & $95.6(83.5)^{\mathrm{b}}$ & $0.7(0.2)^{\mathrm{b}}$ & $5.2(1.2)^{\mathrm{b}}$ \\
\hline
\end{tabular}

Means in the same column followed by distinct superscripts indicate statistical significance (Student $\mathrm{T}$ test, $\mathrm{P}<0.05)$.

Table 4. Relationship between patients who showed low or high S. mutans in saliva and patients diagnosed as Candida-positive (presence of C. albicans on prosthesis or palate).*

\begin{tabular}{cccc}
\hline S. mutans & \multicolumn{2}{c}{ Diagnosis of candidiasis } & \multirow{2}{*}{ Total } \\
\cline { 2 - 3 }$\left(\mathrm{n} \times 10^{4} \mathrm{fcu} / \mathrm{mL}\right)^{* *}$ & Negative & Positive & 16 \\
\hline Low & 11 & 5 & 14 \\
High & 4 & 10 & 30 \\
Total & 15 & 15 & \\
\hline
\end{tabular}

${ }^{*}$ Chi-square $=4.82$, d.f. $=1, \mathrm{p}<0.05$

** cut-off point of $29 \times 10^{4} \mathrm{cfu} / \mathrm{mL}$ of S. mutans (percentile $50 \%$ ).

\section{Discussion}

C. albicans was the major isolated yeast in the selected subjects. This was also observed in other studies $(2,9)$. The predominant site for colonies was the prosthesis indicating the importance of the mechanism of adherence of yeast cells on a non-shedding surface $(6,15)$. Adhesion is the first step for yeast colonization on the oral epithelium, and dentures may become an important source for reinfection (18). For denture stomatitis patients the risk of candidiasis is high since porous acrylic surfaces can provide more biding sites than natural teeth and shedding surfaces as oral mucosa (1).
Shinada et al. (8) observed that the presence of Candida was highest on the mucosal denture surfaces followed by clasp, tongue, and remaining teeth. Therefore, it is not a surprise that a significant number of patients could harbor Candida albicans in the prosthesis as shown in Table 1. From the clinical point of view an endogenously re-colonization of Candida in some patients cannot be disregarded. Candida is usually ubiquitous in the oral mouth and digestive tract. Thus a re-infection can be originated from external and internal sources, or both. Age of the prosthesis, oral hygiene and ability to penetrate the oral mucosa are certainly important variables to be considered for those less successful cases $(1,2)$. How far oral hygiene and the counting of 
S. mutans can influence re-infection, this is still a matter of debate (7).

Recently, many investigations have focus more on biofilm formation than in planktonic cells to explain the bacterial behavior in the in vivo oral environment (19). Regarding candidiasis, few studies have investigated the bacteria-yeast relationship using clinical parameters that can modulate the biofilm formation on different surfaces $(5,10,12)$. It is important to consider bacterial-Candida interactions in the study of fungal virulence. Aspects of the host's microbial community might normally protect against fungal proliferation or might play an important role in the preparation of the fungus for its role in the infection. Also, mixed bacterial-fungal infections might have properties that are distinct from single-species infections (20). These cospecies communities, probably existing as a mixed biofilm, are difficult to treat with antibiotics and antifungals (6).

Saliva and oral hygiene can be important mediators for oral biofilm development. Specific salivary components may act promoting yeast-bacteria co-aggregation and adherence to oral surfaces $(9,4,17)$. Low salivary flow can also facilitate biofilm development and this is certainly a matter of concern when treating old subjects prone to dry mouth related problems $(8,17)$.

In our study, Candida spp cfu values were obtained from biofilm material of dentures or palatal lesions, whereas. $S$. mutans cfu levels were evaluated from saliva samples as an indication of $S$. mutans counting. Although $S$. mutans are major constituents of cariogenic oral biofilms, the saliva counting can be a good indicator of the major oral biofilms in the mouth in many oral conditions $(21,22)$. In fact, a variation of $S$. mutans cells in different sites of the mouth is expected. Therefore, the option of collecting the S.mutans data from saliva was regarded as appropriate. In addition, all procedures were carried out following established guidelines of material collection (16). In any case, considering the cfu counting of S.mutans in the evaluated subjects, one must estimate that in denture oral biofilms there are at least 5-fold more bacteria than those found in saliva. Girad Junior et al. (2) observed that the dental biofilm formed in the presence of sucrose would be an indirect contributing factor for yeast adherence due to an increase in Streptococcus spp. As shown in Tables 1 and 4, most of the subjects with high counts of Candida also had high counts of $S$. mutans. Moreover, subjects with candidiasis and high amounts of S.mutans in the oral mouth were the virtually the same with unfavorable salivary parameters and poor oral hygiene. The question at this point is not if a potentialization of the adherence capacity of Streptococcus mutans and Candida albicans takes place in a biofilm development, but rather if this synergic effect can be estimated or predicted clinically. The clinical implications of these results are that candidiasis treatment can be more effective when including frequent oral hygiene measures to reduce biofilm formation and S.mutans in the oral mouth (23). On the other hand, a risk for dental caries due to Candida is likely as reported by Moalic et al. (24) and Nikawa et al. (25). A low biofilm pH may favor $S$. mutans but Candida can also take advantage of adherence mechanism in such environment.

The observation of lesions types I and II in these subjects indicates that candidiasis was not an acute event in these patients. Poor oral hygiene and unfavorable salivary parameters can probably aggravate this condition by many ways including the Candida-Streptococcus co-aggregation. From the clinical point of view, compliance for oral health instructions can be problematic. Therefore, in addition to oral hygiene instructions, the use of antimicrobials might be an interesting choice to patients with a high $S$. mutans counting and resistant candidiasis.

\section{Conclusions}

It can be concluded that:

1. S. mutans counting was higher in patients with candidiasis and it was associated with low salivary flow and poor oral hygiene;

2. After therapy, it was verified a reduction of $S$. mutans particular in patients with normal salivary parameters; and

3. Streptococcus spp collaborates with Candida spp in the etiology and pathogenesis of denture stomatitis. The use of oral antimicrobial agents may provide a beneficial effect for denture stomatitis patients that are under antifungal therapy and that have poor oral hygiene and unfavorable salivary parameters.

\section{Acknowledgments}

This study is part of a doctoral thesis and it was supported by Lauro Wanderley University Hospital for its realization.

\section{References}

1. Budtz-Jörgensen E. Etiology, pathogeneses, therapy and prophylaxis of oral yeast infections. Acta Odontol Scand 1990;48:61-9

2. Girard Junior B, Landry RG, Giasson L. La stomatite prothétique: etiologie et condérations cliniques. J Can Dent Assoc 1996;62:808-12.

3. Könsberg R, Axéll T. Treatment of Candida - infected denture stomatits with a miconazole lacquer. Oral Surg Oral Med Oral Pathol 1994;78:306-11.
4. Vasconcelos LC, Sampaio MC, Sampaio FC, Higino JS. Use of Punica granatum as an antifungal agent against candidosis associated with denture stomatitis. Mycoses 2003;46:192-6.

5. Linossier A, Vargas A, Villegas R, Chimenos E. Quantitative relationship between salivary level of Streptococcus mutans and Candida albicans in children with Down's syndrome. Med Oral 2002; 7:284-92 
6. Baena-Monroy T, Moreno-Maldonado V, Franco-Martinez F, AldapeBarrios B, Quindos G, Sanchez-Vargas LO. Candida albicans, Staphylococcus aureus and Streptococcus mutans colonization in patients wearing dental prosthesis. Med Oral Patol Oral Cir Bucal 2005; 1:E27-39.

7. Holmes AR, Gopal PK, Jenkinson HF. Adherence of Candida albicans to a cell surface polysaccharide receptor on Streptococcus gordonii. Infect Immun 1995;63:1827-34

8. Shinada K, Ozaki F, Cordiero JG, Okada S, Shimoyama K, Nagao $M$, Ichinose S, Yamashita Y. A morphological study of interactions of Candida albicans and Streptococcus mutans. Kokubyo Gakkai Zasshi 1995;62:281-6.

9. Jorge $A O C$, Koga-Ito $C Y$, Gonçalves CR, Fantinato V, Unterkircher CS. Presença de leveduras do gênero Candida na saliva de pacientes com diferentes fatores predisponentes e de indivíduos controle. Rev Fac Odontol Univ São Paulo 1997;1 1:279-85.

10. El-Azizi MA, Starks SE, Khardori N. Interactions of Candida albicans with other Candida spp. and bacteria in the biofilms. J Appl Microbiol 2004;96:1067-73.

11. Barbieri DSV, Vicente VA, Fraiz FC, Lavoranti OJ, Svidzinski TIE, Pinheiro R L. Analysis of the in vitro adherence of Streptococcus mutans and Candida albicans. Braz i Microbiol 2007;38: 624-31.

12. Shinada K, Teraoka K, Asaka T, Cordeiro JG, Ozaki F, Shimoyama $\mathrm{K}$ et al. Distribution of Candida species and mutans streptococci related to oral conditions in elderly persons. Kokubyo Gakkai Zasshi 1997;64:512-17.

13. Newton AV. Denture Sore Mouth: a possible Ettiology. Br Dent J 1962;357-60

14. Pfaller MA, Houston A, Coffmann S. Application of CHROMágar Candida for rapid screening of clinical specimens for Candida albicans, Candida tropicalis, Candida krusei and Candida (Torulopsis) glabrata. J Clin Microbiol 1996;34:58-61.
15. Sakki TK, Knuuttila MLE, Läärä EL, Anttila SS. The association of yeasts and denture stomatitis with behavioral and biologic factors. Oral Surg Oral Med Oral Pathol Oral Radiol Endod 1997;84:624-9.

16. Krasse B. Risco de cárie: um guia prático para avaliação e controle. $2^{a}$ ed. São Paulo: Quintessence Books; 1988.

17. Gold OG, Jordan HV, Van Houte J. A.selective medium for Streptococcus mutans. Arch Oral Biol 1973;18:1357-64.

18. Noborikawa E, Silveira FRX, Witzel, AL, Lotufo, MA. Biotypes of Candida albicans isolates from the oral mucosa of HIV seropositive and control subjects. Rev Odonto Ciênc 2009;24:258-63.

19. Marsh PD. Role of the oral microflora in health. Microb ecol health dis $2000 ; 12: 130-7$

20. Wargo.MJ, Hogan, DA. Fungal-bacterial interactions: a mixed bag of mingling microbes. Curr Opin Microbiol 2006;9:359-64.

21. Sullivan A, Borgström MK, Granath L, Nilsson G. Number of mutans streptococci or lactobacilli in a total dental plaque sample does not explain the variation in caries better than the numbers in stimulated whole saliva. Community Dent Oral Epidemiol 1996;24:159-63.

22. Hintao J, Teanpaisan R, Chongsuvivatwong V, Ratarasan C, Dahlen $G$. The microbiological profiles of saliva, supragingival and subgingival plaque and dental caries in adults with and without type 2 diabetes mellitus. Oral Microbiol Immunol 2007;22:1 75-81

23. Vasconcelos LCS, Sampaio FC, Sampaio MCC, Pereira MSV, Higino JS, Peixoto MHP. Minimum inhibitory concentration of adherence of Punica granatum Linn (pomegranate) gel against S. mutans, S. mitis and C. albicans. Braz Dent J 2006; 17:223-7.

24. Moalic E, Gestalin A, Quinio D, Gest PE, Zerilli A, Le Flohic AM. The extent of oral fungal flora in 353 students and possible relationships with dental caries. Caries Res $2001 ; 35: 149-55$.

25. Nikawa H, Egusa H, Makihira S, Nishimura M. Ishida K, Furukawa M, Hamada T. A novel technique to evaluate the adhesion of Candida species to gingival epithelial cells. Mycoses 2003;46:384-9. 